\title{
Symbolism, Parable, and Synesthesia in the End of Elisabeth Heinroth's Jenseits der Mauer
}

\section{By Mark Mumford}

Zin Glück lag zertrümmert zu ihren Füßen, das kostbare, am heißensten ersehnte [...] aber dort draußen breitete die Natur ihre unendliche Fülle aus, das unerschöpfliche, starke Leben" (Heinroth, 2:206). With this sentence Elisabeth Heinroth ends her novel Jenseits der Mawer, a story about, among other people and things, a widowed woman of the nobility who wishes to marry again. Jutta von Hadersloh, whose first marriage to an older man had been arranged, now wishes to marry someone her own age and to her own liking: Franz Herger, a government official (Unterstaatssekretär). The only problem is that Jutta has had many affairs over the years, and Herger does not wish to marry someone who has a reputation for having loose morals. He has heard the stories about her and does not want to believe them, but he also does not feel comfortable without some assurance from her that the rumors are not true. So Herger asks Jutta to tell him that the imputations on her character are false and makes his continued wish to marry her dependent on her answer. She could lie and it would make no difference to him, but if she did, Jutta would be denying her whole life and the 


\section{Sophie Journal}

freedom and forthrightness with which she has led it. We find her then at the very end of the novel in the midst of trying to decide what she should declare to Franz Herger about the conduct of her life. In the final four pages (203-206) Jutta is on a morning bird hunt with her friend Klaus Börke and on the very last page (206) she writes and sends the letter containing her decision to Herger. This paper is about the symbolisms present in these final four pages of Jenseits der Maner, especially the symbolic connection between Franz Herger and the male bird (Hahn) which Jutta takes such pains to shoot on her hunting trip with Klaus Börke, as well as the significance of natural elements and how they figure into Jutta's self image in both reflection and experience.

The final pages of Jenseits der Mauer are filled with very interesting relations in symbolism and action. These begin by taking place within the symbolic mind, then finish as allegory in the literal outer world, and finally are played out in actuality while at the same time pointing back to the previous allegory with interesting possible implications.

On pages 201 and 202 Jutta is out in the hunting blind with Klaus Börke and she is thinking about the position she is in and what she might, should, and could do, and why. She thinks how she might just tell Franz, "Ich habe nichts getan, dessen ich mich zu schämen hätte!' dann würde er sie jubelnd in seine Arme schließen, zu seinem Glück, zu ihrem Glück" (Heinroth, 2:201-202). It would be so easy to just lie and everything would be okay. But that word "lie" is not as simple as it seems, because right away in the next paragraph the narrator says that, "Etwas von ihrem alten Wesen, von ihrer sicheren Schwindelfreiheit kam über sie" (Heinroth, 2:202). And that thought, though 


\section{Symbolism, Parable, and Synesthesia}

short-lived, was a pleasant one for her. Oddly enough, what has happened here is that we now have the identification of a "lie" (that is, at least an avoidance of telling the whole truth) with "sichere [...] Schwindelfreiheit," a confident freedom from deception. Strangely, the thought of a casual "little white lie" has caused Jutta to feel a certain innocence.

This apparent contradiction can be explained by recalling that Jutta had been in an arranged marriage with a man much older than herself. Affairs were not uncommon in such situations. Jenseits der Mauer was published in 1924, which puts it right at the end of what has come to be known as "The Age of Reason." One of the ideas popular during this period of time was that if people stopped trying to regulate things and simply left them alone, that nature would balance everything out and things would tend to work correctly. This also applied to natural instincts, so that if, to take marriage as an example, the innate natural sense of a person indicated to them that something was not right with the relationship, then it should not exist (Brinton, 300). In this case, the marriage was only a formal fiction, convenient for some purposes but not others. She had had many extra-marital relationships over the years and had continued to do so after the death of her first husband. Her affairs were an out for her from her loveless marriage and lonely time as a young widow, and, at the time, made her as she describes at the end of the same paragraph, "unschuldig froh. Ja, unschuldig" (Heinroth, 2:202), and then goes on to explain, "Eine Sünderin, die nichts von Sünde weiß" (Heiroth, 2:202). Thrown into a difficult situation, she had managed to create a life somewhat warped, but only because it was a reflection of the terribly difficult marital situation she faced. 


\section{Sophie Journal}

And even of the experience she had given to (and had with) others, she says that they had never seriously affected her ("hatten sie, nie ernstlich berührt") (Heinroth, 2:202). So Jutta's affairs, while they had been enjoyable, were just little games. She could not feel a traitor to love because she had never really loved. This is the reason that the thought of telling Franz Herger the casual lie initially made Jutta feel somehow free of guilt. In a mode reflective of her unnatural marital situation she had been operating in a state of innocent hedonism for quite some time. Of course, she knew that according to the letter of the law her actions were sinful, but she also knew just as strongly in her heart that it was only sensual pleasure: she felt that she had never become emotionally involved. Such a casual lie was full of innocence for Jutta von Hadersloh.

But on this day, things are different for Jutta: right after her feeling of "sichere[...] Schwindelfreiheit" we are told that "dann fühlte sie von neuem den Druck auf ihrer Seele, der das sorglose Auflackern nicht mehr zuließ" (Heinroth, 2:202). The innocence was part of her old self and this weight was something new. The unpleasantness comes from two things: (1) the conflict inherent in being put in a position where she feels she has to tell a lie to someone she really cares about and (2) the problem of the suicide of Ottilie (the governess) whose demise was caused in part because she wanted to follow Jutta's example in living the free, open, and morally lax life. Jutta feels responsible for Ottie's death and hates the thought of lying to Franz Herger, for whom she cares deeply.

Ottilie's death, the fact of which she could not now change, had had a big effect on Jutta and she says that "seitdem war etwas von ihrem alten freiein Selbst verlorengegangen" 
(Heinroth, 2:202). She was, as she says earlier, at least on the inside, "aus dem Gleichgewicht gekommen" (Heinroth, 2:202). But unlike Ottie's death, how she responded to Franz Herger was still to be decided.

At this point we are brought back to Jutta's physical locale as Klaus Börke says, "Hören Sie wohl? Die Heide erwacht" (Heinroth, 2:203). The text from this point to the end of the novel I will treat here as four sections, each one corresponding roughly to the page breaks. The first three form a symbolic exposition reflective of Jutta's thoughts as she is making her decision, and the fourth, of her actually carrying it out. The first three sections may be seen in many of their elements as an allegory of the fourth, which shines back on the three with some intellectually provocative results.

Page 203 to page 204 is a musical theater presentation in baroque splendor. Klaus Börke alerts Jutta that "Die Heide erwacht," and she looks out of the blind. To the east she sees the "leise Grauen," which means roughly "quiet graying." That expression combines sound and color in the first descriptive phrase the text uses for this scene. Then she says, "und mit dem Licht erwachten die Töne." Again here, there is the close association of visual and auditory elements.

Then she names three sounds and where they come from: "der meckernde Ruf der Bekassinen" (the grumbling call of the snipes), "das Pfeifen des Pipers im Moor" (the whistling of the "Piper" [likely a bird of some sort] in the marsh), and "das Flöten der Drossel" (the fluting of the thrush), and calls it a "helle[s] Konzert" (bright concert) (Heinroth, 2:203). Yet once again the association between music and light and color is obvious. Thereafter she hears the sound of the complaint 


\section{Sophie Journal}

("Klageton") of the "Ohreule" (some sort of owl). Then, odd for its lack of appropriateness to the music and light which otherwise rule in this section, a "Rehbock" steps out from the edge of the forest to seek his fodder ("Äsung"). A "Rehbock" (roebuck) is a male of the species of small deer that live in northern Germany where Jenseits der Mauer takes place, and are also to be found throughout the rest of Europe and across middle Asia (Danilkin, 45).

The next paragraph takes the music analogy and makes it even more obvious by actually using the words "Kreszendo" and "Forte." That is, the "Kreszendo des Lebens" and then "die Sonne" rises up behind the "Heidehügel" and the "Kreszendo ist zum Forte angewachsen" (Heinroth, 2:203). Then "die Sonne" is called "die grosse, heiße gütige Lebenspenderin!" The reference clearly emphasizes the femaleness of "die Sonne" both linguistically and in the idea of life giving force ("Lebenspenderin"). In this description we have the first reference in this analogy to heat or a lack thereof. So far everything has been light and sound.

The sun is said to be "groß," "heiß," "gütig," and the giver of life ("Lebenspenderin"). The continuity of the music/light motif from the time that Jutta looks out of the blind to when the sun rises is interesting. What stands out, however, is this one sentence about the roebuck ("Rehbock"): "Dort—etwas Braunrotes, ganz fern, am Waldrand: ein Rehbock, der hervortrat, auf der Wiese seine Äsung zu suchen" (Heinroth, 2:203). This sentence breaks the continuity of the music/light progression in half. It contains no elements of music or light, but he is said to be simply "braunrot" - an ordinary and uninteresting color at best. The roebuck is a male figure and is "ganz fern," but steps 


\section{Symbolism, Parable, and Synesthesia}

forward on the "Wiese" to find himself some breakfast. He is on the edge of the forest. He is neither a central, nor a close element. If he had come close or been jumping or running, he might have been a thing worth noticing. Why is he mentioned then? He breaks up the integrity of an otherwise continuous musical light show like a cell phone ringing from the back of the concert hall during a symphony. The placement of this interruption is significant however: it comes right before the rising of the sun rises.

The sun continues the theme of the previous paragraph of music and light, but is special because it is a climax of sorts: it makes a kind of summary of all of the other previous sounds and colors, and it also introduces heat. The enormous, round, warm, life-giving circle is similar symbolically to the enormous, round, warm, belly of a pregnant woman. Not only do all of the cues as to shape, size, and temperature match, but the idea of providing life is also precisely similar. If the rising sun with all its climax, intensity, and heat is analagous to pregnancy, how did the sun become pregnant?

I would propose that the painfully insignificant roebuck is a likely candidate for this paternity. He preceeds the rising of the pregnant sun directly and is otherwise totally out of place. His actions are aimless except that he is looking for food, i.e. fulfilling an ordinary personal need.

The brief reference to the roebuck in this text is analagous to the chronologically brief physical role the male creature plays in human reproduction. What is surprising is that the male figure is included at all (because it could certainly have been excluded), and that it is shown to be so boring, incidental, and "ganz fern." The beautiful life-giving process, while it nominally requires the 


\section{Sophie Journal}

participation of a male element, is almost completely a female undertaking. The male role is peripheral to the great female symphony of color, light, heat, and life. The male creature would appear to hug the edges ("Waldrand") and we might suppose that he spends his time in the shade of the forest only coming out on the "Wiese" under the light of the female sun to seek his "Äsung." The drama of life according to this text is a female project and the male elements are both naturally and socially peripheral.

The last paragraph on this page is about Jutta's reasons for wanting to see this natural spectacle (the sunrise on the "Heide") and how she experiences it. "Und das mit wachen Sinnen wahrzunehmen: wenn die ernste, stille Heidenatur ihr Auge öffnet dem neuen Tage" (To see it all with senses that are awake: as nature opens her eye to a new day) (Heinroth, 2:203). Nature is "ernst" and "still." "Die Natur" is female and opens her eye to the day. So not only is the sun female, but so also is all of the "Heidenatur." The "Heidenatur" opening her eye to the day is a summary of the previous section with all of the music, color, and light. The text then says that Jutta came out not because she wanted particularly to go hunting, but because she wanted to experience ("erleben") this opening of the eye of "[die] Heidenatur." It says that she came out while it was still night ("zu nächtiger Stunde”) and then "die Lichtquelle hervorbrach und unter ihrer Berührung alle grauen, kalten, stumpfen Töne sich wie im Zauberspiel zur Farbe entzündeten" (Heinroth, $2: 204)$. That is, the sun comes forth and enflames ("entzündeten") all of the gray, cold, and dull ("stumpf") tones ("Töne") into colors. The figurativeness of these expressions is extreme: how can a tone (sound) be gray? "Gray," however, fits 


\section{Symbolism, Parable, and Synesthesia}

in with colors. "Dull" works as both a sound and a color, but "cold" is entirely figurative (i.e. foreign) to both.

"Dann war helle Freude in Juttas Herzen erwacht." Here is another synesthetic expression: bright joy. This is not in the landscape but in Jutta's own heart. What I find interesting is the connection between the "Heidenatur" and Jutta. The text says that the "Heidenatur" opens its eye to the day, but it is Jutta's eyes which open to both. Nature does not literally have an eye, but Jutta has two of them. As before stated, both the "Heidenatur" and the sun are largely female in characterization. Just as nature opens her eye to the life-giving sun and has its sounds turned to color, so Jutta opens her eyes to this process and "dann war helle Freude in Juttas Herzen erwacht." Jutta's observation of nature opening its eye to the day has the same effect on her. She opens her eye to this process and precisely the same thing happens to her that happens to the "Heidenatur." Nature's eye and her eyes are exactly similar because they open to the light and are made colorful by it.

At this point, nature's synesthetic symphony of color, light, heat, and sight ends with "that was then" ("—-damals_-"), "Heute nicht," the bright joy ("helle Freude") that usually awoke ("erwacht") in Jutta's heart did not awaken today because of her problem. In fact, "heute schreckte sie zurück vor dem aufglühenden Tage." Why is the breaking day so terrible for her? "Der Tag war die Wirklichkeit, die Wahrheit_die unerbittliche Notwendigkeit." The day is these three things for Jutta, but why? The phrase, "Mit kalter Helle füllte er ihre Seele," tells us what they are. The "er" here refers to Franz Herger. He is the problem that she must deal with. And "kalter Helle" tells us what those three words mean. Cold light is a rather good way to 


\section{Sophie Journal}

characterize "reality," "truth," and "necessity." These are empty, cold, and lifeless forms which are very different from the the kaleidescope of color and sound from the previous page and certainly different from the warmth of the life-giving sun. He fills her with cold light, and in the next two sentences Jutta decides: "Sie wußte jetzt, was sie zu tun hatte," and "Klar lag das Schicksal vor ihr." Then she talks about the idea that had governed her life, that if you are strong enough to live your life a certain way, then you can live it that way, but then adds that though you may do these things you can't get away from their consequences. It is interesting that she uses the masculine "sein" and "er" throughout this statement. Linguistically it is appropriate because it corresponds nominally to the indefinite pronoun "wer," but it is interesting because it distances the statement from her: she is not a man. At the very least, the text distances this maxim from Jutta by speaking in the masculine idiom, but it may in fact also point its accusing finger at Franz Herger. He is strong enough to demand a certain assurance (that she had been morally upright) from Jutta, but be cannot get away from the consequences of making this demand. Then, in the next paragraph, she talks about her "reiches Leben" and how varied and wonderful it has been, and then she says how many happy hours she had enjoyed, but that "das eine Glück war ihr versagt—das höchste." This "Glück" is not marriage, because she had been married before, and it isn't money, because she is already wealthy. The "Glück" that she so prizes must be true love. Jutta had had many romantic relationships but none that she considered real love.

This next sentence is very hard to understand: "Ein Heiligtum sein dem geliebten Manne ... das Glück, das nur ganz 


\section{Symbolism, Parable, and Synesthesia}

reinen Händen erreichbar ist." Why is "sein" in the infinitive here? It cannot be saying that "dem geliebten Manne" is "ein Heiligtum" because "dem geliebten Manne" is in the dative case. It has to be something which is given to or done for "dem geliebten Manne." Most likely we are missing the past participle. Perhaps it should be understood to mean "Ein Heiligtum sein dem geliebten Manne [bestimmt]." "Ein Heiligtum" refers presumably to Jutta herself since it is intended for "dem geliebten Manne" (Herger), while "das Glück" is likely the loving marriage that Jutta wishes for since it is qualified with: "das Glück, das nur ganz reinen Händen erreichbar ist." This goes back to the problem of the idea that a woman had to be a virgin or she wasn't fit to marry (and of course it didn't matter for a man). The idea is repeated here without modification presumably as one of Jutta's thoughts and it does something to her: "Ein Jammer glühte auf in Juttas Seele, heiß und schmerzlich, ein Zorn auf das Leben, auf ihr Leben..." Jutta now feels rueful or miserable about her own life. This feeling glows, hot and painful in her soul.

Right now Jutta has this hot, hurtful thing burning inside of her, and just at this moment we are brought back to Jutta's actual locale as Klaus Börke says, "Da—sehen Sie?" It would be easy to see this return from her thoughts as a total break in the flow except that Jutta has just had a very painful thought and it never goes away. It's still there, "heiß und schmerzlich," in her soul.

Klaus Börke watches whatever he has seen and Jutta "folgte seinem scharf gespannten Jägerblick." Just then they see it and it is "ein Hahn." Jutta recognizes the male bird "ganz deutlich" by its markings. She recognizes the sounds of its movements. "Er 


\section{Sophie Journal}

schlug mit den Flügeln, tanzte, rodelte-hochaufgerichtet, in höchster Erregung der Kampflust und Liebesbegierde trippelte er über die braune Heide" (Heinroth, 2:205). The words used to describe this "Hahn" are indicative of extended meaning. Birds do not really "dance" as such in the way that that word is usually applied. All in all these words could be used just as easily if not more easily to describe human behavior and motivation, especially "Kampflust" (the desire to fight) and "Liebesbegierde" (a desire for love). They are appropriate to the bird since it is mating season, but they can also apply to Herger. Altogether, the choice of words seems to fit a proud courting man just as well if not better so than it does the mating bird.

Next Jutta immediately wants to shoot the mincing ("trippelte") rooster and says "Jetzt!" Klaus wants to spare the bird, but something came over Jutta, "- -etwas Hartes, Wildes_-sie riß dem Freunde die Büchse aus der Hand-ein Knall." Jutta had shot the "Hahn" which then "schlug mit den Flügeln" and then lay there "weit ausgebreitet." Klaus went to pick up the dead bird, but Jutta did not go with him. Then she became outwardly emotional and began to cry. Upon coming back, Klaus notices that she is crying and is quite astounded, apparently because she didn't show those kinds of vulnerable emotions very often. Then the text says that Klaus felt that "die Frau trug ein Leid, das er nicht von ihr nehmen konnte." This sorrow ("Leid") is probably related to if not identifiable with the "Jammer" (misery) which she experienced just before she shot the bird when thinking about her life.

This hot, painful misery is what caused Jutta to be so eager to shoot the bird when it danced about proudly like her proud Franz Herger. And this hot thing is what causes Jutta to do what 
she does next: she writes her answer in a letter to Franz. She shoots this hot, painful misery as if with a bullet out of the barrel of her own soul directly at him. And just as she shot the "Hahn," she leaves no room in her answer to Franz for following up: she did not follow Klaus to the bird and she shows no intention of having any more contact with Franz. The letter was short and to the point: "Knall."

Then interestingly, she "schloß" the letter. "Schloß" is only one letter different from "schoß," and it isn't unheard of (at least in English) to say that you "fired a letter off..." She then walked to the window and "weit riß sie die beiden Flügel auf." These Fliggel are not the wings of a bird, but the shutters on a window, however the word is the same. Jutta had shot the bird which then beat with its wings and lay "weit ausgebreitet." Implicit in laying in that way is the idea of the wings being spread out as well. There is a symmetry in the shooting of the bird and the closing of the letter, and the twin images of the birds wings spread out and the shutters being pulled open wide.

Indeed, her pulling open the shutters signifies symbolically Franz's deadness to Jutta. She has closed the letter and now opens the shutters. And joyfully, the sign of his death to her, the wide open shutters- his wide open wings—brings Jutta back to the nature that she loves so much. It is significant to note that she could not see out of the window until she opened the shutters. His wings were shutting her in, keeping out the nature that is the giver of life which she loves so much.

And now that the shutters are pulled wide open, "der Atem der Scholle stieg zu der einsamen Frau empor und neue Kraft erfüllte ihre Seele" (Heinroth, 2:206). Clearly, something has changed from Jutta's earlier resignation of: "—damals—heute 


\section{Sophie Journal}

nicht." And that brings us finally again back to the last sentence of the novel: "Ein Glück lag zertrümmert zu ihren Füßen, das kostbare, am heißensten ersehnte...aber dort draußen breitete die Natur ihre unendliche Fülle aus, das unerschöpfliche, starke Leben" (Heinroth, 2:206). This "Glück" lays crushed at her feet; the possibility of her relationship of true love with Franz lays ruined on the floor just like the shot "Hahn" lay on the "Heidegras." But Jutta has chosen bright, warm, life-giving nature and feels very confident in that decision: "die Natur [breitete], ihre unendliche Fülle aus, das unerschöpfliche, starke Leben" (Heinroth, 2:206).

The first section examined created a fitting introduction to the nature that Jutta so loves and which sustains her, while the second section, that in which she reflects on the coldness and emptiness that Franz Hergers refusal has caused her, tells us why she chooses to "shoot" him. The third section is an allegory of Jutta's decision to reject Herger, and the fourth and last portion shows her actually carrying it out. This four page conclusion to Jenseits der Mauer is a masterful example of synesthesia, parable, and symbolism from Elisabeth Heinroth, one of the great authors of the nineteenth-century. 


\section{Symbolism, Parable, and Synesthesia}

\section{Works Cited}

Brinton, Crane. A History of Western Morals. New York: Harcourt, Brace and Company, 1959.

Danilkin, A. and A.J.M Hewison. Behavioural Ecology of Siberian and European Roe Deer. London: Chapman and Hall, 1996.

Heinroth, Elisabeth. Jenseits der Mauer. 2 Volumes. http://sophie.byu.edu/literature/texts.htm. 